\title{
ANALISIS KESANTUNAN BERBAHASA PADA KEGIATAN PEMBELAJARAN KELAS VIII E SMPN 2 KOTA BENGKULU TAHUN AJARAN 2016/2017
}

\author{
Ayu Wulan Dari ${ }^{1}$, Dian Eka Chandra W. $^{2}$, dan Marina Siti Sugiyati ${ }^{3}$ \\ ${ }^{1,2,3}$ Program Studi Pendidikan Bahasa dan Sastra Indonesia \\ Jurusan Pendidikan Bahasa dan Seni \\ FKIP Universitas Bengkulu
}

\begin{abstract}
Abstrak
Penelitian ini mempunyai sasaran untuk mengetahui penyimpangan dan pematuhan prinsip kesantunan berbahasa pada kegiatan diskusi kelas, mata pelajaran bahasa Indonesia, dalam hal pemilihan kata, dan cara berdiskusi yang santun pada siswa kelas VIII E SMPN 2 Kota Bengkulu serta implikasinya dalam pembelajaran bahasa Indonesia. Jenis penelitian yang dipakai oleh peneliti yaitu metode deskriptif dengan pendekatan kualitatif. Subjek penelitian ini yaitu siswa kelas VIII SMPN 2 Kota Bengkulu, pada mata pelajaran bahasa Indonesia. Hasil penelitian ini menunjukkkan bahwa data penyimpangan prinsip kesantunan berbahasa terdiri dari empat maksim, meliputi maksim kebijaksanaan, penghargaan, kedermawanan, dan kesederhanaan.. Penyimpangan prinsip kesantunan berupa penyimpangan satu maksim dan dua maksim berbeda sekaligus dalam satu tuturan. Penyimpangan prinsip kesantunan dua maksim terdiri atas penyimpangan prinsip kesantunan maksim kedermawanan dan penghargaan, kebijaksanaan dan kedermawanan, dan kebijaksanaan dan penghargaan. Selanjutnya, data pematuhan prinsip kesantunan berbahasa terdiri dari enam maksim, meliputi maksim kebijaksanaan, penghargaan, kedermawanan, kesederhanaan, permufakatan, dan kesimpatian. Pematuhan prinsip kesantunan berupa pematuhan satu maksim, dua maksim, dan tiga maksim berbeda sekaligus dalam satu tuturan. Pematuhan prinsip kesantunan dua maksim terdiri atas pematuhan prinsip kesantunan maksim kebijaksanaan dan kedermawanan, kebijaksanaan dan kesederhanaan, penghargaan dan kebijaksanaan, penghargaan dan permufakatan, serta penghargaan dan kesederhanaan.
\end{abstract}

\section{Kata Kunci: Kesantunan Berbahasa, Kegiatan Pembelajaran}

\begin{abstract}
This research has objective to know deviation and compliance of language politeness principle in class discussion activity, Indonesian language subjects, in terms of word selection, and polite way of discussion to students of class VIII E SMPN 2 Kota Bengkulu and the implication in learning Indonesian language. Type of research used by the researcher is descriptive method with qualitative approach. The subjects of this study are students of class VIII SMPN 2 Kota Bengkulu, on the subjects of Indonesian language. The results of this study indicate that the data of deviation of language politeness principle consists of four maxims, including maxim of wisdom, appreciation, generosity, and simplicity. The deviation of the principle of politeness consists of the deviation of one maxim and two different maxims at once in one speech. The deviation of the principle of modality of two maxims consists of deviations of the principle of generosity of maxim of generosity and of appreciation, wisdom and generosity, and wisdom and reward. Furthermore, the data on the compliance of the principle of linguistic politeness consists of six maxims, including maxim of wisdom, reward, generosity, simplicity, consensus, and conclusions. Adherence to
\end{abstract}


the principle of politeness in the form of one maxim, two maxims, and three different maxims at once in one speech. The adherence to the principle of modality of two maxims consists of adhering to the principle of maximized politeness of wisdom and generosity, wisdom and simplicity, respect and wisdom, respect and consent, and appreciation and simplicity.

\section{Keywords: Speech Language, Learning Activity}

\section{PENDAHULUAN}

Kesantunan, kesopansantunan, atau etika adalah tatacara, adat, atau kebiasaan yang berlaku dalam masyarakat. Kesantunan merupakan aturan perilaku yang ditetapkan dan disepakati bersama oleh suatu masyarakat tertentu sehingga kesantunan sekaligus menjadi prasyarat yang disepakati oleh perilaku sosial (Masinambouw dalam Chaer: 1995). Oleh karena itu, kesantunan ini biasa disebut "tatakrama". Kesantunan dapat dibagi menjadi tiga, yaitu kesantunan berpakaian, kesantunan berbuat, dan kesantunan bertutur atau berbahasa. Kesantunan berbahasa tercermin dalam tatacara berkomunikasi lewat tanda verbal atau tatacara bertutur.

Menurut Yule (2006:81), dalam usaha untuk mengungkapkan diri mereka, orang-orang tidak hanya menghasilkan tuturan yang mengandung kata-kata dan struktur-struktur gramatikal saja, tetapi mereka juga memperlihatkan tindakantindakan melalui tuturan-tuturan itu.

Menurut Brown dan Levinson dalam Chaer (2010:11) teori tentang kesantunan berbahasa itu berkisar atas nosi muka atau wajah (face) dalam "citra diri" yang bersifat umum dan selalu ingin dimiliki oleh setiap anggota masyarakat. Namun, hal itu juga berkaitan dengan konteks. Konteks dalam tindak tutur adalah hal yang tidak dapat dipisahkan.

Kesantunan berbahasa perlu diperhatikan ketika berkomunikasi dengan orang lain agar tidak terjadi kesalahpahaman. Perilaku bertutur yang dikatakan santun adalah apabila seseorang memperhatikan etika berbahasanya terhadap mitra tutur. Etika berbahasa itu sendiri erat kaitannya dengan norma-norma sosial yang berlaku dalam masyarakat. Etika berbahasa ini antara lain akan mengatur apa yang harus dikatakan pada waktu dan keadaan tertentu dan ragam bahasa apa yang wajib kita gunakan dalam situasi sosiolinguistik dan budaya tertentu.

Terdapat beberapa etnik budaya dalam masyarakat Bengkulu yaitu etnik rejang, serawai, melayu, dan etnik pendatang lainnya seperti jawa, batak, dan minang. Oleh karena itu, fenomena kesantunan masyarakat Bengkulu dibatasi oleh nilai budaya masing-masing etnik yang mereka patuhi, terutama dalam komunikasi verbal (Wardhana: 2006). Meski setiap etnik budaya memiliki nilai sosial dan kebahasaan yang berbedabeda, namun secara umum konsep kesantunan masyarakat Bengkulu sangat berkaitan erat dengan tutur bahasa yang disampaikan kepada mitra tutur, yang dapat dinilai dari pilihan kata yang digunakan dan intonasi bahasa.

\section{Konsep Kesantunan}

Kesantunan bersifat relatif di dalam masyarakat. Ujaran tertentu bisa dikatakan santun di dalam suatu kelompok masyarakat tertentu, akan tetapi di kelompok masyarakat lain bisa dikatakan tidak santun. Menurut Leech (1983) kesantunan yaitu menyangkut hubungan antara peserta komunikasi yaitu penutur dan pendengar, maka penutur menggunakan kalimat dalam 
tuturannya dengan santun tanpa
menyinggung.
Masinambouw (dalam Chaer, 1995: 172) menambahkan bahwa sistem bahasa mempunyai fungsi sebagai sarana berlangsungnya interaksi manusia di dalam masyarakat, maka berarti di dalam tindak laku berbahasa haruslah disertai norma-norma yang berlaku di dalam budaya itu. Sistem tindak laku berbahasa menurut norma-norma budaya ini disebut etika berbahasa atau tata cara berbahasa.

\section{Kesantunan Berbahasa}

Menurut Rahardi (2005: 35) penelitian kesantunan mengkaji penggunaan bahasa (language use) dalam suatu masyarakat bahasa tertentu. Masyarakat tutur yang dimaksud adalah masyarakat dengan aneka latar belakang situasi sosial dan budaya yang mewadahinya. Adapun yang dikaji di dalam penelitian kesantunan adalah segi maksud dan fungsi tuturan. Fraser (dalam Rahardi, 2005: 38-40) menyebutkan bahwa sedikitnya terdapat empat pandangan yang dapat digunakan untuk mengkaji masalah kesantunan dalam bertutur.

1) Pandangan kesantunan yang berkaitan dengan norma-norma sosial (the social-norm view). Dalam pandangan ini, kesantunan dalam bertutur ditentukan berdasarkan norma-norma sosial dan kultural yang ada dan berlaku di dalam masyarakat bahasa itu. Santun dalam bertutur ini disejajarkan dengan etiket berbahasa (language etiquette).

2) Pandangan yang melihat kesantunan sebagai sebuah maksim percakapan (conversational maxim) dan sebagai sebuah upaya penyelamatan muka (facesaving). Pandangan kesantunan sebagai maksim percakapan menganggap prinsip kesantunan (politeness

principle) hanyalah sebagai

pelengkap prinsip kerja sama (cooperative principle).

Menurut Chaer (2010: 10) secara singkat dan umum ada tiga kaidah yang harus dipatuhi agar tuturan kita terdengar santun oleh pendengar atau lawan tutur kita. Ketiga kaidah itu adalah (1) formalitas (formality), (2) ketidaktegasan (hesistancy), dan (3) kesamaan atau kesekawanan (equality or camaraderie). Jadi, menurut Chaer (2010: 11) dengan singkat bisa dikatakan bahwa sebuah tuturan disebut santun kalau ia tidak terdengar memaksa atau angkuh, tuturan itu memberi pilihan tindakan kepada lawan tutur, dan lawan tutur itu menjadi senang.Kesantunan berbahasa tercermin dalam tatacara berkomunikasi lewat tanda verbal atau tatacara berbahasa.

\section{Penggolongan Kesantunan Berbahasa Menurut Leech}

Kesantunan

berbahasa

menggambarkan kesantunan atau kesopansantunan penuturnya. Kesantunan berbahasa pada hakikatnya harus memperhatikan empat prinsip, yaitu penerapan prinsip kesantunan, penghindaran pemakaian kata tabu (taboo), penggunaan eufemisme, yaitu ungkapan penghalus, dan penggunaan pilihan kata honorifik. Penggunaan kata tabu di dalam kelas contohnya kata "mati" yang terkesan lebih kasar dibanding kata "meninggal".

Leech (1983: 678) menyebutkan dalam suatu interaksi para pelaku memerlukan prinsip lain selain prinsip kerja sama yaitu prinsip kesantunan 'politeness principle'. Prinsip kesantunan mempunyai enam maksim kesantunan yakni:

1) Maksim Kebijaksanaan (Tact Maxim)

Gagasan dasar maksim kebijaksanaan 
dalam prinsip kesantunan adalah bahwa para peserta pertuturan hendaknya berpegang pada prinsip untuk selalu mengurangi keuntungan dirinya sendiri dan memaksimalkan keuntungan pihak lain dalam kegiatan bertutur.

2) Maksim Kedermawanan (Generosity Maxim)

Dengan maksim kedermawanan atau maksim kemurahan hati, para peserta pertuturan diharapkan dapat menghormati orang lain. Penghormatan terhadap orang lain akan terjadi apabila orang dapat mengurangi keuntungan bagi dirinya sendiri dan memaksimalkan keuntungan bagi pihak lain.

3) Maksim Penghargaan (Approbation Maxim)

Di dalam maksim penghargaan dijelaskan bahwa orang akan dapat dianggap santun apabila dalam bertutur selalu berusaha memberikan penghargaan kepada pihak lain. Dengan maksim ini, diharapkan agar para peserta pertuturan tidak saling mengejek, saling mencaci, atau saling merendahkan pihak yang lain. Dalam maksim ini Chaer menggunakan istilah lain, yakni maksim kemurahan.

4) Maksim Kesederhanaan (Modesty Maxim)

Di dalam maksim kesederhanaan atau maksim kerendahan hati, peserta tutur diharapkan dapat bersikap rendah hati dengan cara mengurangi pujian terhadap dirinya sendiri.

5) Maksim Permufakatan (Agreement Maxim)

Maksim permufakatan sering disebut dengan maksim kecocokan. Di dalam maksim ini, ditekankan agar para peserta tutur dapat saling membina kecocokan atau kemufakatan di dalam kegiatan bertutur.

6) Maksim Kesimpatisan (Sympath
Maxim)

Dalam maksim kesimpatisan, diharapkan agar para peserta tutur dapat memaksimalkan sikap simpati antara pihak yang satu dengan pihak lainnya. Sikap antipati terhadap salah seorang peserta tutur akan dianggap sebagai tindakan tidak santun

\section{Ciri Kesantunan Berbahasa}

Kesantunan berbahasa seseorang, dapat diukur dengan beberapa jenis skala kesantunan. Chaer (2010: 63) menyatakan bahwa yang dimaksud dengan skala kesantunan adalah peringkat kesantunan, mulai dari yang tidak santun sampai dengan yang paling santun. Rahardi (2005: 66-67) menyebutkan bahwa sedikitnya terdapat tiga macam skala pengukur peringkat kesantunan yang sampai saat ini banyak digunakan sebagai dasar acuan dalam penelitian kesantunan. Dalam model kesantunan Leech, setiap maksimum interpersonal itu dapat dimanfaatkan untuk menentukan peringkat kesantunan sebuah tuturan.

\section{Kesantunan dalam Pembelajaran}

Pembelajaran adalah proses,
perbuatan, cara mengajar atau mengajarkan, atau segala sesuatu mengenai mengajar (KBBI, 1990:13). Menurut Lindgren dalam Soekamto (1997: 5) fokus sistem pendidikan mencakup tiga aspek, yaitu: (1) siswa, yang paling penting sebab tanpa siswa tidak aka nada proses pembelajaran, (2) pembelajaran yaitu apa yang dihayati siswa apabila mereka belajar, bukan apa yang harus dilakukan dosen untuk mengajar tetapi apa yang akan dilakukan siswa untuk mempelajarinya, dan (3) situasi belajar, yaitu lingkungan tempat terjadinya proses pembelajaran yang mencakup semua faktor yang mempengaruhi siswa atau proses pembelajaran seperti guru, kelas 
dan interaksi di dalamnya, dan sebagainya.

\section{Kesantunan Berdiskusi}

Menurut Suryosubroto (2009: 167), diskusi adalah suatu percakapan ilmiah oleh beberapa yang tergabung dalam satu kelompok untuk saling bertukar pendapat tentang sesuatu masalah atau bersama-sama mencari pemecahan mendapatkan jawaban dan kebenaran atas suatu masalah. Sejalan dengan pendapat di atas, menurut KBBI edisi ketiga (1990: 269) diskusi adalah pertemuan ilmiah yang membahas suatu masalah. Dalam kegiatan pembelajaran diperlukan metode diskusi untuk memecahkan suatu permasalahan.

\section{Penelitian yang Relevan}

Terdapat tiga penelitian yang relevan dengan penelitian ini yaitu yang pertama adalah penelitian oleh I Gusti Ayu Mirah Trisnadewi (2014) dari Universitas Gadjah Mada (UGM). Penelitiannya berjudul Kesantunan Berbahas TokohTokoh dalam Serial Drama Korea God's Quiz: Sebuah Kajian Sosiopragmatik. Setelah dilakukan analisis data ditemukan bahwa tuturan-tuturan tokoh-tokoh banyak mengandung pematuhan dan pelanggaran maksim prinsip kesantunan, yaitu maksim kebijaksanaan, maksim penerimaan, maksim kedermawanan, maksim kerendahan hati, maksim kesepakatan dan maksim kesimpatian dalam semua season. Dari keenam maksim tersebut, maksim penerimaan yan g sering dipatuhi dan maksim kerendahan hati yang paling sering dilanggar oleh tokoh-tokoh dalam drama God's Quiz.

\section{METODE}

Metode penelitian yang dipakai oleh peneliti yaitu metode deskriptif dengan pendekatan kualitatif. Metode deskriptif, yaitu metode paparan hasil temuan berdasarkan fakta yang ada atau fenomena yang diperoleh berdasarkan data yang dikumpulkan dari lapangan. Tujuan dari penelitian deskriptif ini yaitu untuk membuat pencandraan atau deskripsi secara sistematis, faktuan, dan akurat mengenai situasi-situasi atatu kejadian atau fenomena yang terjadi saat penelitian sedang dilaksanakan. Data dari penelitian ini berupa tuturan lisan dalam diskusi kelas antara guru dan siswa di kelas VIII E SMP N 2 Kota Bengkulu. Subjek penelitian ini yaitu siswa dan guru kelas VIII SMPN 2 Kota Bengkulu, pada mata pelajaran bahasa Indonesia.

Adapun yang menjadi objek penelitian adalah penyimpangan dan pematuhan prinsip kesantunan berbahasa, dalam hal pemilihan kata dan cara berdiskusi yang santun. Dalam penelitian ini, metode pengumpulan data yang digunakan adalah metode simak. Metode simak yang digunakan adalah teknik SBLC (simak bebas libat cakap), karena peneliti tidak melibatkan diri dalam kegiatan percakapan yang dilakukan oleh subjek penelitian. Dalam penelitian kualitatif ini, yang berperan sebagai instrumen utama adalah orang atau biasa disebut dengan human instrument, dan orang tersebut adalah peneliti sendiri (dalam Sugiyono, 2007: 2). Dalam melakukan penyimakan, peneliti menggunakan alat perekam sebagai alat pendukung instrumen untuk memudahkan tahap pencatatan ke dalam kartu data. Peneliti juga menggunakan lembar rekaman data yang digunakan untuk mengklasifikasikan data sesuai indikator-indikator kesantunan yang dilanggar dan dipatuhi. Instrumen lain yang digunakan adalah indikator-indikator kesantunan berbahasa yang diturunkan dari teori kesantunan berbahasa yang dikemukakan oleh Leech. Indikator ini didasarkan dari indikator-indikator kesantunan dalam proses belajar 
mengajar, kemudian dikelompokkelompokkan berdasarkan maksimmaksim kesantunan dari Leech. Analisis data adalah proses pelacakan dan pengaturan secara sistematis transkrip wawancara, data lapangan, dan bahanbahan lain yang dikumpulkan untuk meningkatkan pemahaman terhadap bahan-bahan agar dapat dipresentasikan semuanya kepada orang lain. Analisis data menurut Sugiyono (2008: 135) adalah proses mencari dan menyusun secara sistematis data yang diperoleh dari hasil wawancara, catatan lapangan dan dikumentasi dengan cara mengorganisasikan data ke dalam kategori, menjabarkan unit-unit, melakukan sitesa, menyusun ke pola, memilih mana yang penting dan akan dipelajari, dan membuat kesimpulan sehingga mudah dipahami oleh diri sendiri maupun orang lain.

Penelitian kesantunan berbahasa dalam kegiatan diskusi kelas VIII E SMPN 2 Kota Bengkulu menggunakan teknik triangulasi untuk memeriksa keabsahan data yang telah diperoleh dari hasil penelitian. Menurut Sugiyono (2007) diartikan sebagai teknik pengumpulan data yang bersifat menggabungkan dari berbagai teknik pengumpulan data dan sumber data yang sudah ada. Triangulasi adalah teknik pemeriksaan keabsahan data dengan memanfaatkan sesuatu yang lain di luar data untuk keperluan pegecekan dan pembanding terhadap data. Dalam penelitian ini, peneliti membuat triangulasi dengan tujuan untuk melakukan pengecekan dan keterpercayaan hasil temuan.

\section{HASIL PENELITIAN.}

Berdasarkan hasil analisis data penelitian prinsip kesantunan berbahasa pada kegiatan pembelajaran kelas VIII E SMPN 2 Kota Bengkulu ini berupa deskripsi penyimpangan dan pematuhan prinsip kesantunan berbahasa yang terjadi pada kegiatan diskusi kelas di kelas VIII E SMPN 2 Kota Bengkulu. Berdasarkan data yang diperoleh dalam penelitian, ditemukan penyimpangan dan pematuhan prinsip kesantunan berbahasa. Keseluruhan data yang terkumpul berdasarkan jumlah kartu data yakni 53 kartu data tuturan.

\section{Penyimpangan Satu Maksim Maksim Kebijaksanaan}

Pada prinsip kesantunan maksim kebijaksanaan ini, penutur hendaknya menggunakan diksi-diksi yang halus dalam diskusi, tuturan yang tidak langsung, tidak memaksakan pendapatnya serta menggunakan kata "maaf" ketika ingin membantah diskusi. Tuturan berikut adalah contoh penyimpangan maksim kebijaksanaan. Penyimpangan maksim kebijaksanaan pada data (1) dapat dilihat bahwa penanya melakukan penyimpangan maksim kebijaksanaan indikator ke 4 yaitu menggunakan kata "maaf"ketika ingin membantah diskusi. Dari tuturan penanya terlihat bahwa penanya tidak menggunakan kata maaf yang dianggap lebih santun ketika kita ingin menyanggah suatu pendapat orang lain. Seharusnya ketika kita ingin menyanggah atau tidak setuju dengan pendapat kelompok lain bisa menggunakan kata 'maaf' terlebih dahulu. Karena dengan begitu kita sudah mematuhi maksim kebijaksanaan yang mengutamakan keuntungan orang lain.

\section{Maksim Kedermawanan}

Pada prinsip kesantunan maksim kebijaksanaan ini, penutur hendaknya tidak memaksakan orang lain untuk melakukan hal yang dia inginkan, meminta dengan kalimat tanya bukan kalimat perintah, menanggapi pendapat orang lain dengan diksi yang halus, dan memberikan kesempatan kepada orang lain untuk 
berpendapat. Tuturan berikut yang termasuk ke dalam penyimpangan maksim kedermawanan.

\section{Maksim Penghargaan}

Pada prinsip kesantunan maksim penghargaan ini, penutur hendaknya mengucapkan "terima kasih" ketika dipuji atau dikritik, menghargai dan menghormati pendapat orang lain, memberikan pujian yang jujur, dan tidak menyinggung mitra tutur. Tuturan berikut adalah contoh penyimpangan maksim penghargaan.

\section{Maksim Kesederhanaan}

Pada prinsip kesantunan maksim kesederhanaan ini, penutur hendaknya mengucapkan tidak memamerkan kelebihannya terhadap orang lain, berbicara apa adanya, tidak menunjukkan sifat angkuh dan sombong saat berdiskusi, dan berprasangka baik terhadap orang lain. Tuturan berikut adalah contoh penyimpangan maksim kesederhanaan.

\section{Penyimpangan Dua Maksim \\ Maksim Kebijaksanaan dan Maksim Kedermawanan \\ Penyimpangan \\ maksim \\ kebijaksanaan dan maksim \\ kedermawanan dapat dilihat pada data berikut:}

(11) Moderator : OK, memang semua berawal dari merokok tetapi bagi kelompok kami perhatian dari orang tua lebih penting. Bukan begitu temanteman? Coba pendapat yang lain dikemukakan?

Peserta Diskusi : iya memang betul, saya setuju dengan Anda bahwa perhatian orang tua lebih penting. Terimakasih atas tambahannya.Konteks:Moderatormenan ggapi pertanyaan dari peserta diskusi Penyimpangan maksim kebijaksanaan dan maksim kedermawanan pada data (11) di atas disebabkan oleh tuturan moderator yang memaksakan pendapatnya di dalam diskusi, tuturan tersebut tentu menyimpang dari maksim kebijaksanaan. Kemudian moderator juga memaksa orang lain untuk mengemukakan pendapatnya dengan mengatakan "coba pendapat yang lain kemukakan". Dari tuturan tersebut dapat disimpulkan ba hwa moderator memaksa peserta diskusi untuk melakukan hal yang dia inginkan.

\section{Maksim Kebijaksanaan dan Maksim Penghargaan}

Penyimpangan maksim kebijaksanaan dan maksim penghargaan dapat dilihat pada data berikut:

(14) Penyaji : kalau menurut kami, itu kembali ke diri masingmasing, semua nya tidak terlepas dari kesadaran diri sendiri.

Penanya :lah, tadi katanya orang tua yang lebih penting, jadi yang betul gimana?

Konteks : Penyaji menjawab pertanyaan dari peserta diskusi

(Data no 03.27)

Data (14) menunjukkan bahwa penanya melakukan penyimpangan prinsip kesantunan maksim kebijaksanaan yaitu dengan tidak menggunakan diksi yang halus serta menggunakan tuturan langsung. Tuturan dari penanya juga termasuk penyimpangan maksim penghargaan karena tidak menghargai dan menghormati pendapat orang lain. Seharusnya pemilihan diksi yang halus akan menjadikan tuturan menjadi lebih santun.

\section{c. Maksim Kedermawanan dan Maksim Penghargaan}

Penyimpangan maksim kedermawanan dan maksim penghargaan dapat dilihat pada data berikut: 


Penanya : saya mau bertanya
bagaimana cara kita
biar terhindar dari
pergaulan bebas,
menurut saya
penjelasan kelompok
tadi tidak begitu jelas.

Konteks : Peserta diskusi bertanya kepada kelompok.

(Data no 02.14)

Data (15) di atas menunjukkan bahwa tuturan dari penanya telah menyimpang maksim kedermawanan karena tidak menanggapi pendapat orang lain dengan diksi yang halus serta menyimpang dari maksim penghargaan karena tuturan tersebut dapat menyinggung orang lain. Pemilihan diksi yang lebih halus dalam bertanya dan menanggapi pendapat orang lain akan dapat menjadi tuturan yang lebih santun sehingga tidak menyinggung perasaan orang lain. Data (16) di bawah ini juga menunjukkan penyimpangan maksim kedermawanan dan penghargaan.

\section{Pematuhan prinsip kesantunan berbahasa menurut Leech pada kegiatan diskusi kelas dalam pembelajaran Bahasa Indonesia}

Berdasarkan hasil penelitian, jumlah pematuhan prinsip kesantunan berbahasa pada kegiatan diskusi kelas siswa VIII E SMPN 2 kota Bengkulu berjumlah 38 kartu data tuturan. Data pematuhan prinsip kesantunan berbahasa terdiri dari enam maksim, meliputi maksim kebijaksanaan, penghargaan, kedermawanan, kesederhanaan, permufakatan, dan kesimpatian. Pematuhan prinsip kesantunan berupa pematuhan satu maksim, dua maksim, dan tiga maksim berbeda sekaligus dalam satu tuturan. Pematuhan prinsip kesantunan dua maksim terdiri atas pematuhan prinsip kesantunan maksim kebijaksanaan dan kedermawanan, kebijaksanaan dan kesederhanaan, penghargaan dan kebijaksanaan, penghargaan dan permufakatan, serta penghargaan dan kesederhanaan.

\section{Pematuhan Satu Maksim \\ Maksim Kebijaksanaan}

Pematuhan maksim kebijaksanaan dapat dilihat pada data berikut.

(17) Moderator: perkenalkan kami dari kelompok 3 akan mempresentasikan hasil diskusi kami. Wacana yang berjudul "Kenakalan dikalangan pelajar" yang akan dijelaskan oleh Dinda, kepada saudara Dinda kami persilakan.

Guru : Yang lainnya diam silahkan disimak dulu.

Konteks

:Pada saat moderator
membuka presentasi,
moderator
memperkenalkan anggota
kelompoknya dan tema
yang akan mereka
diskusikan.

(Data no. 01.01)

Data (17) menunjukkan bahwa terdapat pematuhan prinsip kesantunan maksim kebijaksanaan, karena moderator membuka presentasi dengan mempersilahkan anggota kelompoknya dengan kata lain moderator menggunakan diksi atau pilihan kata yang halus sehingga isi dari tuturan mederator tersebut dianggap santun.

\section{Maksim Kedermawanan}

Pematuhan maksim kedermawanan dapat dilihat pada data di bawah ini. 
(29) Guru : : waktunya sudah habis. Silahkan satu kelompok maju kedapan, nanti yang judulnya yang sama itu yang mengomentari yang dulu. Nah kelompok berapa dulu yang maju ini?

Siswa

Konteks : Guru meminta kelompok untuk memulai kegiatan diskusi

(Data no. 05.49)

Data (29) menunjukkan bahwa terdapat pematuhan prinsip kesantunan maksim kedermawanan, karena tuturan yang dihasilkan oleh guru saat meminta kelompok untuk memulai kegiatan diskusi menggunakan kalimat tanya bukan kalimat perintah. Sesuai dengan maksim kedermawanan yakni memaksimalkan keuntungan bagi pihak lain. Dengan guru bertanya kepada kelompok siswa yang sudah mengerjakan maka siswa yang merasa sudah siap akan merasa diuntungkan.

\section{Maksim Penghargaan}

Pematuhan maksim penghargaan dapat dilihat pada data berikut.

$\begin{array}{ll}\text { (31) Guru } & \text { : Itu saja diskusi kita hari } \\ \text { ini, waktunya sudah } \\ \text { habis ketemu minggu } \\ \text { depan, terima kasih } \\ \text { untuk hasil diskusi yang } \\ \text { bagus dari kelompok } \\ \text { hari ini. }\end{array}$

diskusi

(Data no. 05.53)

Data (31) menunjukkan bahwa terdapat pematuhan prinsip kesantunan maksim penghargaan karena saat menyimpulkan hasil diskusi tuturan guru tersebut mengandung pujian yang jujur untuk siswanya. Sehingga guru berusaha memberikan pnghargaan kepada kelompok diskusi yang baik dengan memberikan pujian yang jujur.

\section{Maksim Kesederhanaan}

Pematuhan maksim kesederhanaan dapat dilihat pada data berikut.

(32) Penanya : Baiklah jawaban dari kelompok anda sangat mendukung argumen dari kelompok kami. Dan saya sangat setuju dengan meningkatkan iman kita bisa mengurangi hal-hal buruk di era globalisasi ini.

Penyaji :terima kasih kelompok Yuni. Mungkin kelompok kami memberikan jawaban sesuai dengan pengetahuan kami yang masih minim dan perlu banyak belajar lagi, tapi semoga bermanfaat.

Konteks : Penyaji berusaha menjawab pertanyaan kelompok penanya.

(Data no. 04.40)

Data (32) menunjukkan bahwa terdapat pematuhan prinsip kesantunan maksim kesederhanaan, karena penyaji berusaha rendah hati dan tidak memamerkan kelebihannya yang mampu menjawab pertanyaan penyanya dengan sangat baik. Dengan demikian tuturan penyaji termasuk kedalam maksim kesederhanaan indikator 13 yakni tidak memamerkan kelebihannya terdahap orang lain.

\section{Maksim Kesimpatian}

Pematuhan maksim kesimpatian dapat dilihat pada data berikut.

(33) Penanya: Baiklah terima kasih atas kesempatannya, saya fikir jawaban yang diberikan oleh kelompok anda sudah benar, hanya saja kurang 


\begin{abstract}
tepat saja. Disini saya mencoba menambahkan bahwa dampak era globalisasi ini masih banyak sekali.

Moderator: terima kasih atas masukannya kelompok agung

Konteks: Penanya berusaha menambahkan jawaban atas kelompok penyaji.

(Data no. 05.54)

Data (33) menunjukkan bahwa terdapat pematuhan prinsip kesantunan maksim kesimpatian karena penanya berusaha menambahkan jawaban dari kelompok penyaji walaupun tau bahwa jawaban itu kurang tepat. Tetapi penanya menunjukkan rasa simpati dengan berusaha membantu agar jawaban dari kelompok penyaji terlihat lebih sempurna.
\end{abstract}

\section{Maksim Permufakatan}

Pematuhan maksim permufakatan dapat dilihat pada data (34) berikut.

(34) moderator

: merangkul atau membimbing anak, yang bertugas merangkul yaitu orang tua. Bagaimana Dinda setuju?

Penanya : ya, saya setuju, jawaban yang sangat bagus. Terima kasih.

Konteks: Penanya menerima jawaban kelompok penyaji

(Data no. 02.17)

Data (34) menunjukkan bahwa terdapat pematuhan prinsip kesantunan maksim permufakatan karena penanya mampu menerima kesepakatan hasil diskusi dan tidak memaksakan pendapatnya, dengan mengucapkan kata "iya saya setuju" terlihat bahwa penanya berusaha untuk menerima jawaban dari moderator.

\section{PENUTUP}

\section{Kesimpulan}

Berdasarkan hasil penelitian dan analisis data pada bab IV, didapat simpulan dari hasil penelitian yaitu sebagai berikut:

1. Bentuk penyimpangan prinsip kesantunan berbahasa terdiri dari empat maksim, meliputi maksim kebijaksanaan, penghargaan, kedermawanan, dan kesederhanaan.. Penyimpangan prinsip kesantunan berupa penyimpangan satu maksim dan dua maksim berbeda sekaligus dalam satu tuturan. Penyimpangan prinsip kesantunan dua maksim terdiri atas penyimpangan prinsip kesantunan maksim kedermawanan dan penghargaan, kebijaksanaan dan kedermawanan, dan kebijaksanaan dan penghargaan. Adapun faktor yang mempengaruhi terjadinya penyimpangan prinsip kesantunan pada beberapa maksim dalam kegiatan diskusi tidak terlepas dari beberapa faktor penyebab yaitu; (1) penutur tidak dapat membedakan situasi serius dengan bercanda. (2) Penutur tidak dapat mengendalikan emosinya.. (3) Penutur mengkritik secara langsung atau terangterangan. (4) Penutur merendahkan mitra tutur. Penutur tidak menghargai pendapat dari mitra tutur dengan berbicara menggunakan diksi yang tidak santun. (5) Penutur menyombongkan diri atau memuji diri sendiri di hadapan mitra tutur.

2. Bentuk pematuhan prinsip kesantunan berbahasa terdiri dari enam maksim, meliputi maksim kebijaksanaan, penghargaan, kedermawanan, kesederhanaan, permufakatan, dan kesimpatian. Pematuhan prinsip kesantunan berupa pematuhan satu maksim, dua maksim, dan tiga maksim berbeda sekaligus dalam satu 
tuturan. Pematuhan prinsip kesantunan dua maksim terdiri atas pematuhan prinsip kesantunan maksim kebijaksanaan dan kedermawanan, kebijaksanaan dan kesederhanaan, penghargaan dan kebijaksanaan, penghargaan dan permufakatan, serta penghargaan dan kesederhanaan. Berdasarkan penjelasan mengenai pematuhan prinsip kesantunan dalam kegiatan diskusi dapat disimpulkan bahwa terdapat beberapa faktor yang menjadikan tuturan tersebut bersifat santun dalam kegiatan diskusi yaitu; (1) Penutur mampu mengungkapkan ketidaksetujuan tanpa memojokkan mitra tutur. (2) Penutur mampu memberikan tanggapan positif terhadap mitra tutur. (3) Penutur mampu berhatihati dalam pemilihan kata. (4) faktor lain yang ikut berpengaruh yakni saat berjalannya diskusi, terutama saat ingin mempersilahkan sesorang yakni menggunakan kata "terima kasih", dengan begitu saat diskusi berlangsung tuturan seseorang yang menggunakan kata "terima kasih" akan terdengar lebih santun dan mematuhi prinsip kesantunan. (5) Saat bertutur, penutur tidak menyinggung mitra tutur. (6) Penutur mampu memperhatikan pesan yang ingin disampaikan, baik itu dari segi pemilihan kata maupun penyampaian sebuah tuturan tersebut.

\section{Saran}

Memperhatikan hasil penelitian dan pembahasan yang telah dilakukan, maka penulis mengajukan saran-saran yang berkaitan dengan penelitian ini, sebagai berikut:
1. Bagi siswa, penerapan prinsip kesantunan berbahasa perlu ditingkatkan, baik dalam lingkungan di sekolah maupun di lingkungan masyarakat karena akan berpengaruh dengan perkembangan kebahasaan dan tingkah laku anak.

2. Bagi peneliti, penelitian tentang kesantunan berbahasa perlu ditingkatkan, karena sangat berguna dalam proses komunikasi dengan orang lain terutama masalah kesantunan dalam berbahasa.

3. Bagi pembelajaran di sekolah, materi prinsip kesantunan berbahasa ini dapat digunakan sebagai materi tambahan yang diimplementasikan dalam pembelajaran dan dapat dikaitkan dalam muatan pendidikan karakter agar tuturan yang dihasilkan siswa akan terdengar santun ketika sedang berkomunikasi dengan mitra tuturnya.

\section{DAFTAR PUSTAKA}

Chaer, Abdul. 2010. Kesantunan Berbahasa. Jakarta: Rineka Cipta.

Chaer, Abdul dan Leonie Agustina. 1995. Sosiolinguistik Perkenalan Awal. Jakarta: Rineka Cipta.

Departemen Pendidikan Nasional. 1990. Kamus Besar Bahasa Indonesia (Edisiketiga). Jakarta: Balai Pustaka.

Leech, Geoffrey N. 2011. Prinsip-prinsip Pragmatik. Jakarta: Universitas Indonesia. (Terjemahan M.D.D. Oka). Buku asli 1983. Principles of Pragmatics. London: Longman.

Rahardi, Kunjana. 2005. Pragmatik Kesantunan Imperatif Bahasa Indonesia. Jakarta: Erlangga. 
Sugiyono. 2008. Metode Penelitian Administrasi. Bandung: Alfabeta.

Suryosubroto. 2009. Proses Belajar Mengajar Di Sekolah. Jakarta: Rineka Cipta.
Soekamto, Toeti. 1997. Teori Belajar dan Model-model Pembelajaran. Jakarta: PAU-PPAI Universitas Terbuka.

Yule, George. 2006. Pragmatik. Yogyakarta: Pustaka Pelajar. 